\title{
THE RETABLES OF CADIZ AND JEREZ IN THE 17TH AND 18TH CENTURIES
}

B Y

JOSEPH A. B A I R D

Respectfully dedicated to the memory of Don Manuel Toussaint.

HE increase in wealth of western Andalusia in the 18 th century, due
partly to the fact that Cádiz continued to be an outlet for Spanish trade with the colonies, and that Jerez was important as a wine center, provided ample resources for the redecoration of a number of church interiors. ${ }^{1}$ Most of the actual building fabrics in this area date from an earlier period; but there was extensive "improvement" throughout the decades from 1740 to 1800 . In Cádiz, one finds a peculiar variant of Rococo-Mannerism that is unlike work in other parts of Spain. Furthermore, there does not appear to be much direct connection with nearby Portugal, where salomonicas or classicistic columns dominate almost all retable design in the 18 th century. ${ }^{2}$

Portuguese Rococo is especially confined to the north of that country; and one finds the rather curious phenomenon of little patches of Rococo interest in both Spain and Portugal, with few contacts of contiguous national areas. Thus in the north of Portugal there is the same granite as in Spanish Galicia; and the architecture of both areas utilizes the severe harmony of grey stone and white stucco. But the 18 th century in Galicia, ${ }^{3}$ especially at Santiago and Ia Coruña, is quite different from the 18th century work of, say, Viana do Castelho - not distant in northern Portugal. Thus, too, in the south of Portugal there are numerous 
instances of the fashion, even the almost too giddy preoccupation with motifs from the Rococo (in such towns as Evora): but Lisbon is closer to the spirit of Italianate classicism as interpreted by J. F. Ludwig.

There are retables in the towns from the southern Portuguese border, leading along the southern coast of Spain to Cádiz and Jerez, that have rocaille motifs in their ornamental répertoire: but rarely do we find anything so purely Rococo as, for instance, some of Cayetano Acosta's work in Sevilla. One can not safely assume any more than peripheral connections between Portugal and southern Spain at this period (after 1740), with the exception of certain minor features in the churches of Cádiz (and Salamanca). Each country contains areas which interpret the source books of the international Rococo with considerable fidelity - Portugal in general (outside of court circles) doing this with great consistency. But in Sanlucar de Barrameda ${ }^{5}$ and Cádiz the principal retable type is a distinctive one - never seen in Portugal, but based on a late 17 th century type from Cádiz itself.

The compositional origins of the important 18 th century Cádiz retable type go back to the 17 th century. ${ }^{6}$ Of outstanding historic importance is the retablo mayor in Santo Domingo at Cádiz (Fig. 1). Romero de Torres in Provincia de Cádiz" says that it was "hecho a todo costo en Génova" (1694 or 1636?). ${ }^{8}$ Constructed of various polychromatic marbles and jasper, it is one of the most purely Italian Baroque retables in Spain. The custom of not only importing Italian workmen (begun in the early 16th century) but whole sculptural ensembles from work shops in Genoa or Naples is not uncommon in Spain, or in Portugal as late as the 18th century. Retables, however, since they have to be planned to fit a definite architectural space, are rarely imported unless the whole conception of architecture and decoration comes from one hand (such as the chapel of São João at São Roque in Lisbon, by Vanvitelli).

The retablo mayor of Santo Domingo, Cádiz, is one of a three piece ensemble for that church - the other works being smaller transept retables in the same style and material. Fundamentally, the composition of the retablo mayor is not far from the early 17th century Sevillian scheme of Montañes: ${ }^{9}$ but the emphasis and total effect is quite different. The first level is organized with four great Salomonic columns, enclosing three niches, the largest being in the center. The second level echoes this arrangement on a smaller scale. But the most important aspect of the whole design is that the central grouping of niches does not exactly correspond to the main horizontal division of levels. Thus, the central 
niche of the first level (bottom) is slightly higher than the niches at either side. The inner pair of Salomonic columns in this first level support inward-facing halves of broken pediments, and a kind of nichebaldachin straddles the upper part of the first level center and the lower part of the second level center. Above the niche-baldachin is a high-relief panel in marble of the Crucifixion. The arrangement of parts gives a dominant verticality to the center of the retable, reminding one of the integration of levels at the center of a retable in what I have called the "central Andalusian" retable type, although the latter is distinctly 18th century. (I have discussed this "central Andalusian" type in a doctoral thesis for Harvard University in 1951.)

Whether or not Francisco Hurtado, or any of the later practioners of the "central Andalusian" style, were either directly inspired by Italian 17 th century prototypes ${ }^{10}$ or by works in Spain such as this Cádiz retable has not yet been documented. There is certainly some direct influence of Italian polychromy in marble on Hurtado (The Capilla del Crocefisso at Monreale cathedral ${ }^{11}$ is symptomatic of the type of work in or near Palermo which relates to Granadine polychromatic marble work), or his pupils such as de Bada. Polychromatic marble retables are rare outside of Sevilla, Granada or Cordoba; in Cádiz, I know of only one other major marble retable, following the time of the retablo mayor at Santo Domingo. ${ }^{12}$

Aside from the material used, the most striking features of the Santo Domingo retablo mayor are the powerful salomónicas and the grouping of central elements. At Santiago in Cádiz, the retablo mayor (Fig. 2) is obviously related in design to that of Santo Domingo. ${ }^{13}$ Here, at the end of the 17th century, the salomonicas have been moved from the retable proper to serve as massive framing elements. In a sense, this is a magnification of the similar pairing of salomónicas at Santo Domingo, with their inward-facing, broken pedimental sections. The composition of the Santiago retablo mayor is close to that of Santo Domingo, although there is not the same importance given to the first level.

All levels are approximately the same in height, excepting the flanking niches at the third level. There is, too, a more widely distributed spotting of surface accents here.

The only break with the established horizontal divisions comes in the first level, where the central niche is placed higher than the flanking niches. There is not quite the same strong vertical emphasis in the center as we noted at Santo Domingo. Instead, smaller pairs of inward-facing, 
broken pediments are used to divide the attention between niches and framing columns of the two outer sections of the first level, the central niche and framing columns of the second level, and the outer sections of the third level. ${ }^{14}$ The ornamental repertoire at Santiago is distinctly mid or post mid 17th century. It is based on late auricular Mannerism ${ }^{15}$ - a very developed instance of which can be seen in Córdoba.

Following this 17 th century work, the big retables of Cádiz date principally from the period after 1750 . The most important examples come from the churches of San Francisco and El Carmen. There are also interesting variants of the type in Santa Maria, and in a number of peripheral towns, like Sanlucar de Barrameda. The retablo mayor in San Francisco, formerly known as Nuestra Señora de los Remedios (Fig. 3), must date after the rebuilding of 1705 - and at least seventy years afterwards. Romero de Torres ascribes the retable to the early 17 th century, but apparently without ever having seen it: ${ }^{10}$ for his facts clearly refer to the retable which the present one has replaced. Stylistically this retable is of that peculiar Gadean persuasion that is close to the Rococo in its last phases. There are rocaille elements on the retable itself, as there are on the other important retables in Cádiz; and in the pendentives of the dome here at San Francisco one can see the elaborate intertwining of rocaille motifs that slightly pre-date the retable itself. Despite the incredible richness of these late 18th century Gadean works, which are Rococo rather than Neo-Classic in spirit, there is a distinct premonition of the coming classicistic style in them. Columns are solid; the estipite has little or no vogue here in Cádiz. The salomonica of nearby Portugal has no importance in 18th century interior work of this area, although it continues to be esteemed for portal frames on facades. ${ }^{\mathbf{1 7}}$

Compositionally the retablo mayor of San Francisco is closer to the Italianate work in Santo Domingo (Fig. 1), than to the interpretation of it in Santiago. The central parts are linked into a strong vertical movement, and the levels of these central parts do not correspond to the main horizontal level divisions. The conception is certainly full of bravura, but it is not completely unified. A number of minor ornamental accents contribute to a feeling of restless surfeit comparable to that on the retablo mayor at San Juan de Dios in Granada, which is of a different ornamental persuasion.

Slightly later, distinctly more Neo-Classic, is the retablo mayor in El Carmen at Cádiz (Fig. 4). (There are also many smaller aisle retables here, of extremely interesting form.) The retablo mayor and the retable 
in the right transept are of a closely related style. The retablo mayor is distinctly "central Andalusian" in composition - with a large relief occupying the center of the second level, such as can be seen at Osuna or Ecija. ${ }^{18}$ The cornice above each of the Iarge cylindrical, fluted columns in the first level is not only molded into a capricious outline above the columns, but is "pushed up" in characteristic "central Andalusian" fashion over the tabernacle in the center of the first level. The smaller retable in the right transept also has a relief in its second level, but the cornice is not so integrally connected to the frame of this relief as in the retablo mayor. (The canopy crown, seen in the Colegiatas of Osuna and Jerez, is used on this transept retable at EI Carmen, as it is in a narrow retable in the transept - both crowns being shot with a glory of rays.)

The possibility of some Portuguese influence in this area, but never in a purely Rococo form, may be seen not only in the use of salomonicas on the aisle retables but also in the balcony-boxes at either side of the retablo mayor. This theatric arrangement of the apse is very common in Portugal both in the south and north: it rarely occurs in Spain at this period. One example, however, is Las Monjas del Corpus Christi at Salamanca. Such conventions combined with the Hispanic retable are indicative of the occasional inter-working of two national traditions in this area.

Aside from the Salomonic columned retables in the right aisle and cylindrical shafts of the left aisle retables here at El Carmen, there are aisle retables (Fig. 5) with very peculiar columns. These are not true salomonicas in the Churriguera tradition. They have either a deeply cut flute (Fig. 5) that defines the sharp helical arris of the twisted column or else a kind of undercutting that leaves the column hollow. ${ }^{10}$ Dependent from the Corinthianesque capitals are swags of drapery that fall quite far down on the helices. Both central pair of columns - that is, on either retable of these two aisle examples- carry flattened and cut-out volutes, which project obliquely from the surface of the retable. Both have framed elements in their second level; on one, a curvetting frame about a glassed-in Crucifixion (Fig. 5), and on the other, a lobed frame about an escutcheon; and both have a number of pure rocaille accents on the main upper and outer molding of the retable.

These two retables in $\mathrm{El}$ Carmen are close in style to a tabernacle in the church of San Miguel in Jerez de la Frontera (Fig. 6) ; obviously all were planned, and possibly executed, by the same hand. The tabernacle 
in the Sagrario of San Miguel has more definitely undercut columns, so that the hollow effect is enhanced; and the flattened volutes with their cut-out sections here build up to a kind of second tabernacle over the first level, with a figure of the Virgin at the very top. The rocaille motifs on the semicircular-headed frame over the tabernacle represent some of the most perfect traceries of this kind anywhere. What the immediate origins of this type of retable or tabernacle are would be hard to say: but they seem to stem from certain ornamental plates of Bérain, which have the same hollow twisted columns, the fanciful projection of volute and moldings, the lacy icing of rocaille motifs. Bérain's influence is also seen in the ornament on the facade of the Cathedral of Murcia - designed by Jaime Bort: and it is not inconceivable that a book of ornament which served there might have passed into the hands of a Jerez or Gadean craftsman. Certainly there are no direct sources for this work in Spain or Portugal itself: its lightness and unarchitectural quality are much closer to prints than to actual works of the period.

In the church of Santa Maria in Cádiz - the oldest foundation in the city- there are a number of works from the 18th century. Of chief importance are two retables - one the retablo mayor (Fig. 7) and the other in a samall chapel parallel to the nave of the church. The latter chapel has an inscription which states that a door was opened to the chapel in 1757. This might be considered a terminus ante quem for the interior decoration here (on both stylistic and inscriptional grounds). It is rather early if anything, and I would be inclined to put the chapel and the retablo mayor at about 1775. Both are based on the type which appeared first in the Italian retable of Santo Domingo and a little later in Santiago: but there are significant modifications which show how endlessly inventive these Hispanic designers were. They were never content merely to copy: a work must undergo a change to suit both the fashion of the time and the whim (or more seriously, the plan) of the new interpreter. Whatever one may think of the individual quality of these retables in southern Spain, one can certainly not cavil at the magnificent sense of design that underlay such work - an attitude with great respect for traditional forms, but never servilely imitating.

At El Carmen the exigencies of the apse space, in which the retablo mayor (Fig. 4) had been placed, forced the exclusion of niches on either side of the framed relief at the second level. Here at Santa Maria the scale of the retable is such that these niches may be accommodated. ${ }^{20}$ In its basic composition, then, this retablo mayor is extremely close to 
E1 Carmen's retablo mayor (even to the appearance of the Portuguese box-balconies at either side of the retable as at El Carmen). There are here four richly ornamented columns in the first level - major vertical accents with niches between the pairs of columns. In the center the use of a deep niche, tabernacle and high relief in ascending order is marked, as at El Carmen. The ornamental repertoire here is more Rococo: and the columns of the first level have the richness of rocaille motifs that we have seen in its most developed instance at El Salvador, Sevilla, in the proscenium-retable there. ${ }^{21}$

One extremely significant thing about this retablo mayor in Santa Maria is the way in which massing of high-relief decoration above and below the side niches on the first level suggests a kind of ornamental niche-pilaster - an echo of the type of subordinate vertical accent that had first appeared in the retables of Hurtado, notably that of Santiago in the Cathedral of Granada. Here, as in the work of Lorenzo Rodriguez in the city of Mexico, these niche-pilasters are still subordinate to the dominant verticals of the columns: it is only in later 18th century Mexico that the ornamental niche-pilasters assert themselves as the principal vertical accents and the column is done away with completely. (Despite the overlay of Rococo ornament here, the columns are still definitely cylindrical, and in the upper level of the retable one can see the garland-wrapped colonnettes that announce the Neo-Classic current underlying much of Gadean work.)

In Jerez, with its somewhat less numerous examples of great retables in this period, it is a pleasure to discover the superb work in San Mateo of Andres Benitez. Replacing an earlier work by Gáspar del Aguila of 1578 , the present retablo mayor is datable to c. 1770 or 1780 (Fig. 8). In its more pronounced emphasis on classicist columns, it relates to the strongly neo-classicist works of Murcia, such as the retablos mayores of San Pedro and La Merced. In both cities, Jerez and Murcia, there is apparent a resurgence of interest in the scale and authority of the Italian Boroque, combined with certain characteristic 18th century features such as a delicate scattering of rocaille ornament. In terms of its iconographic legibility, the retablo mayor ranks very high; there is a fine sense of proportion in the emphasis on various saints and angelic retainers. The designer has cleverly suggested the effect of a half-opened tabernacle in the arrangement of central columns and pedimental sections, accentuating the protection afforded the Virgin in her niche; and the figure of Saint Matthew in the upper center. Common to this area are the curvetting 
moldings surrounding the Crucified Christ at the top of the retable. Notable, in a purely ornamental sense, is the use of the faldoncito (underneath the upper tier of side niches), relating the work of Jerez to that of Galicia and of the Granada-Cordoba area. There is a type of niche-pilaster created in these superimposed side niches, but the power of the columns overwhelms them here.

In Jerez and Cádiz the minor retables tend to be more interesting than those around Sevilla. For instance, the retable in the Sagrario of San Mateo at Jerez is certainly not inspired, but its parts are cleanly ordered and sparkle with the customary surface agitation of the period. Or note, on a smaller scale, the little retable and tabernacle of the right side of the nave at Santo Domingo in Jerez (Fig. 9). Here the ecstatic outline of the cornice frame of the retable serves as the perch for a band of angelic musicians. One might also mention the draperyhung retable in a corner of the Colegiata in Jerez (Fig. 10). Definitely Rococo in ornamental repertoire (as that in Santo Domingo just noted), it is particularly interesting as showing the kind of cross-hatch pattern on flat background surfaces which animates background surfaces, like the superb fibre patterns that one finds in Querétaro, Mexico, where draped crowns (as in Santa Rosa) are also to be noted.

A variant of the estipite retable needs brief mention seen also in the Colegiata of Jerez. In this type, the retable acts as a background screen for the figure of a Crucified Christ, the whole being enclosed in a deep molding following its cruciform shape (Fig. 11). This occupies the position of the first level niche or tabernacle on most retables, and is connected with the second level in the central Andalusian retable manner. (In this work we note again the important use of stucco drapery around the retable, the whole cascading down from an almost ludicrously small crown.)

The most unusual minor retable in this corner of Spain is a retable in San Francisco, Cádiz (Fig. 12). The whole retable is reduced to $a$ foliate screen, with articulation only around the (formerly) subordinate niches. The side niches on the first level are framed with tall estipite columns whose cornice rises in a semicircle above the niche. Between the niche and this semicircular cornice arch there is an over-niche decoration culminating in sunbursts - a unique placement and instance of this motif in Spain, at this period but obviously inspired by a custodia. The niche in the second level, with its high relief panel, is given a deep and quasi-trilobed frame. Thus the most important pseudo-architectural accents 


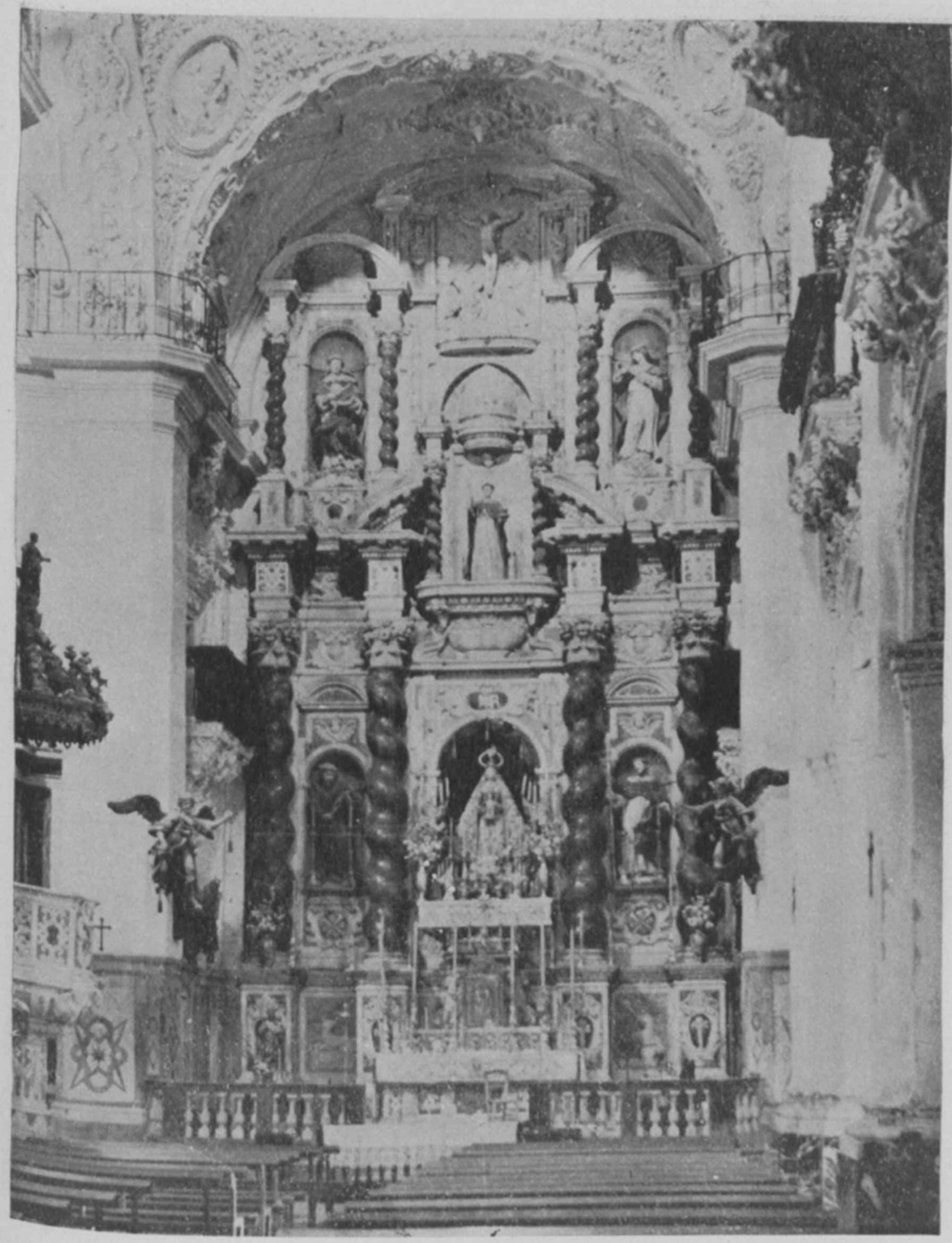

1. Santo Domingo, Cádiz. Retablo mayor. 


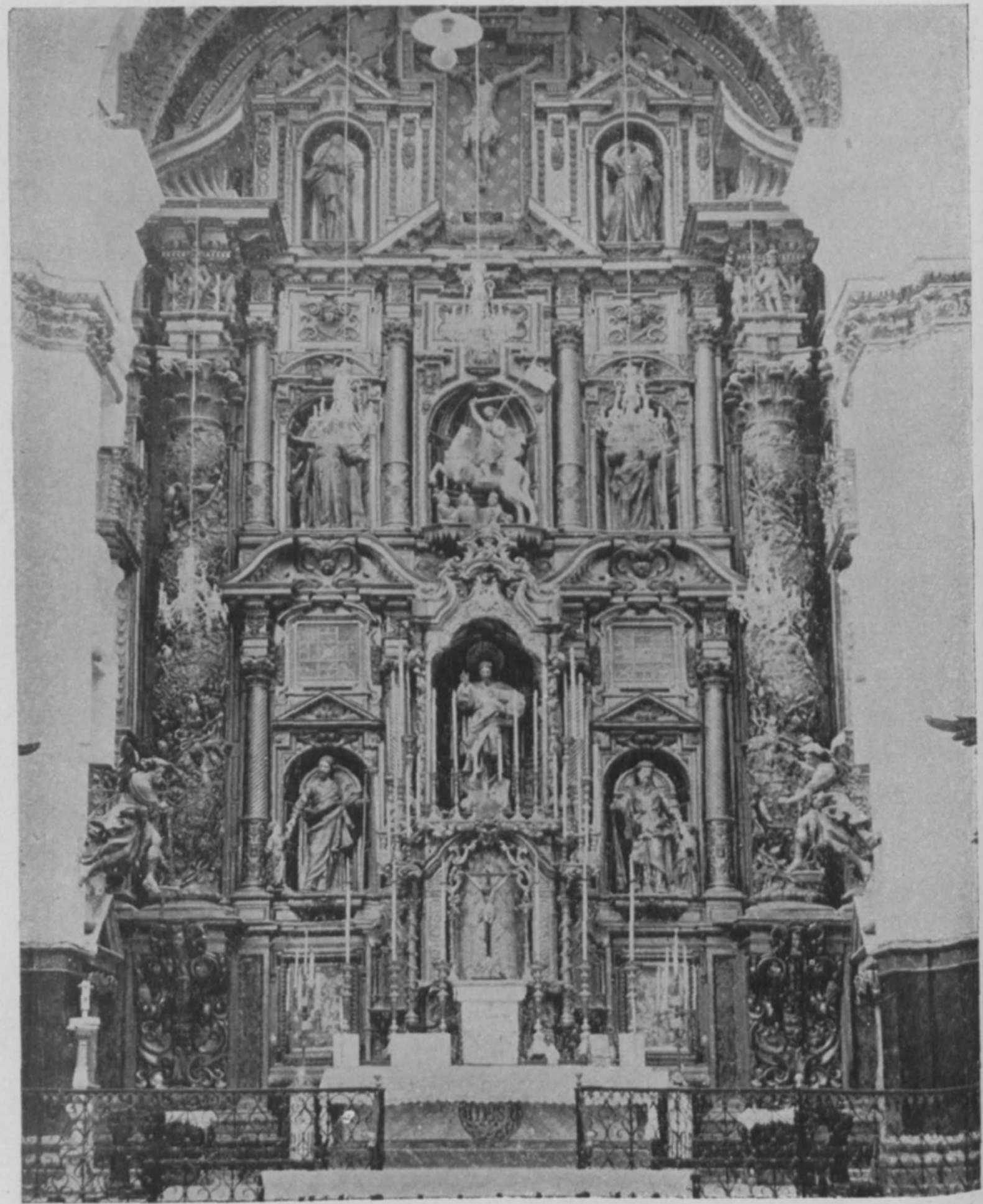

2. Santiago, Cádiz. Retablo mayor. 


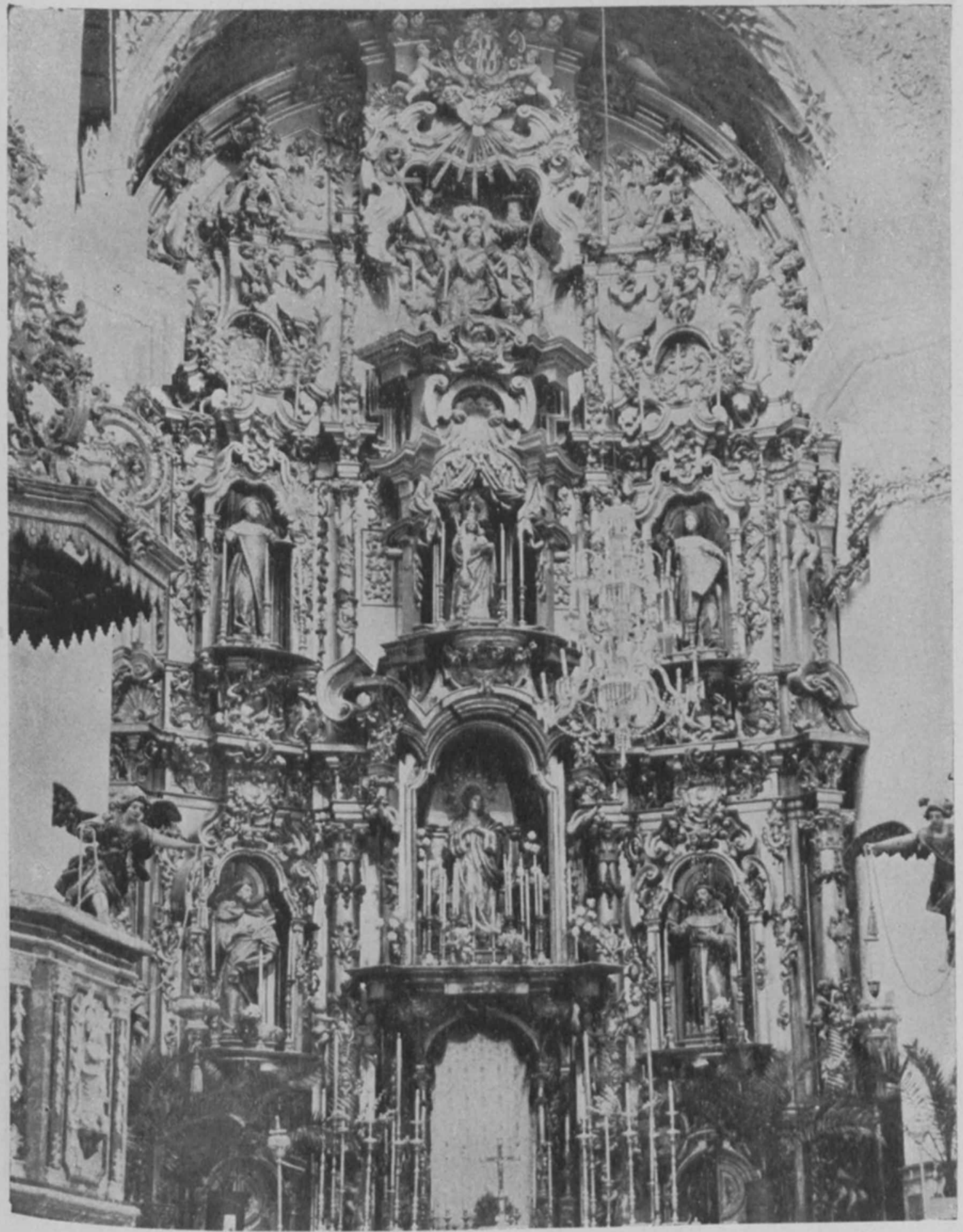

3. San Francisco, Cádiz. Retablo mayor. 


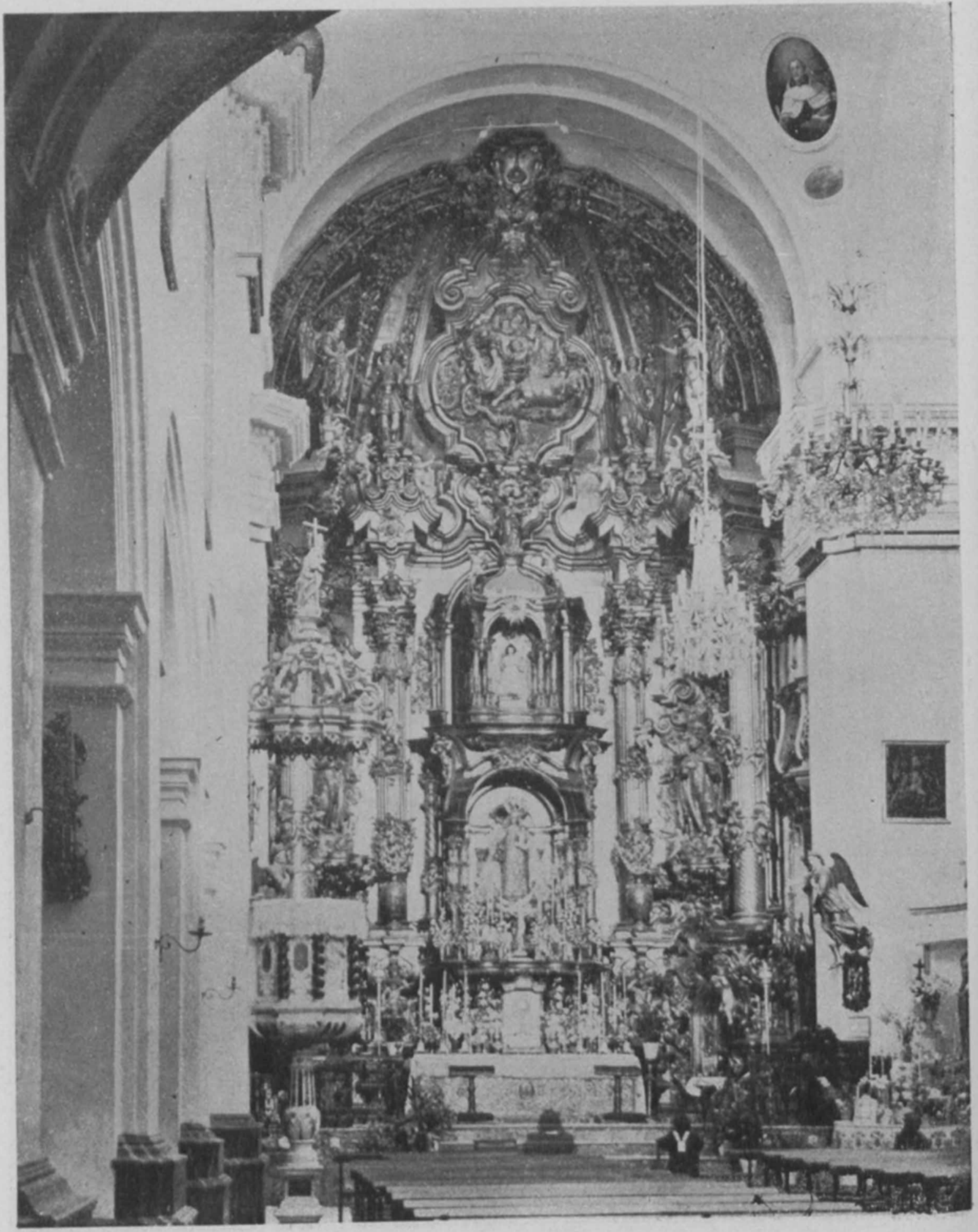

4. El Carmen, Cádiz, Retablo mayor. 


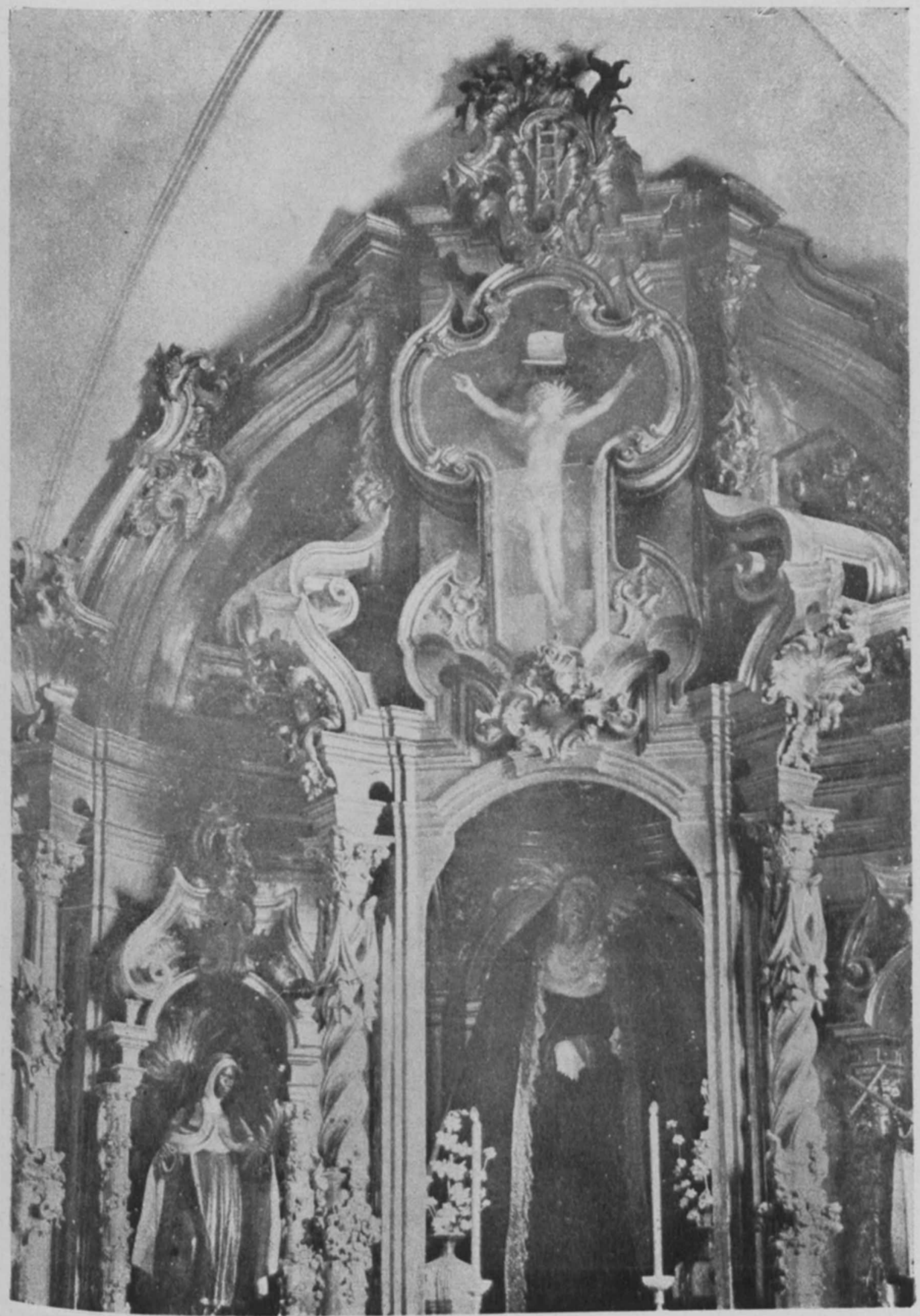

5. El Carmen, Cádiz. Retablo pequeño lateral. 


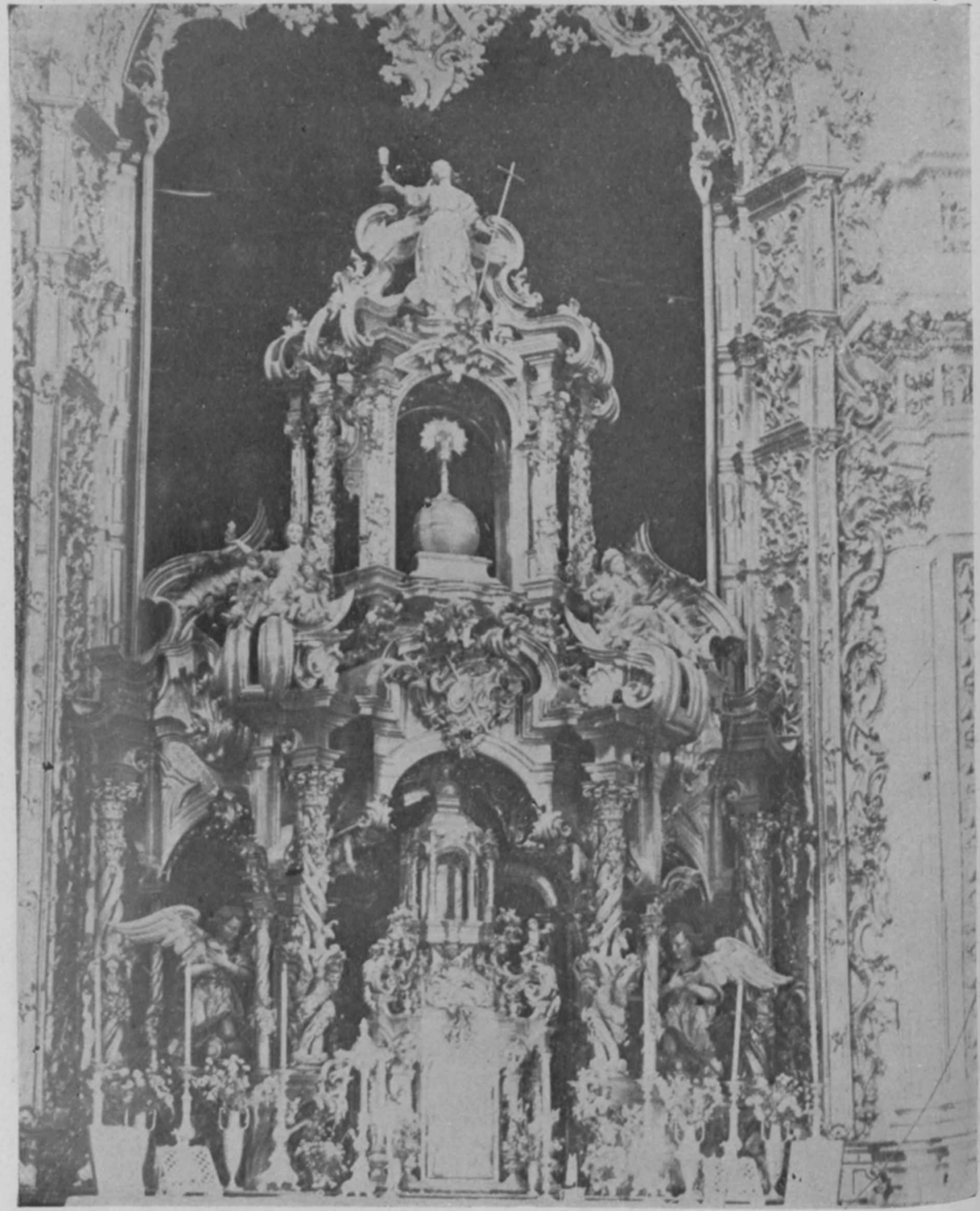

6. San Miguel, Jerez. Tabernáculo. 


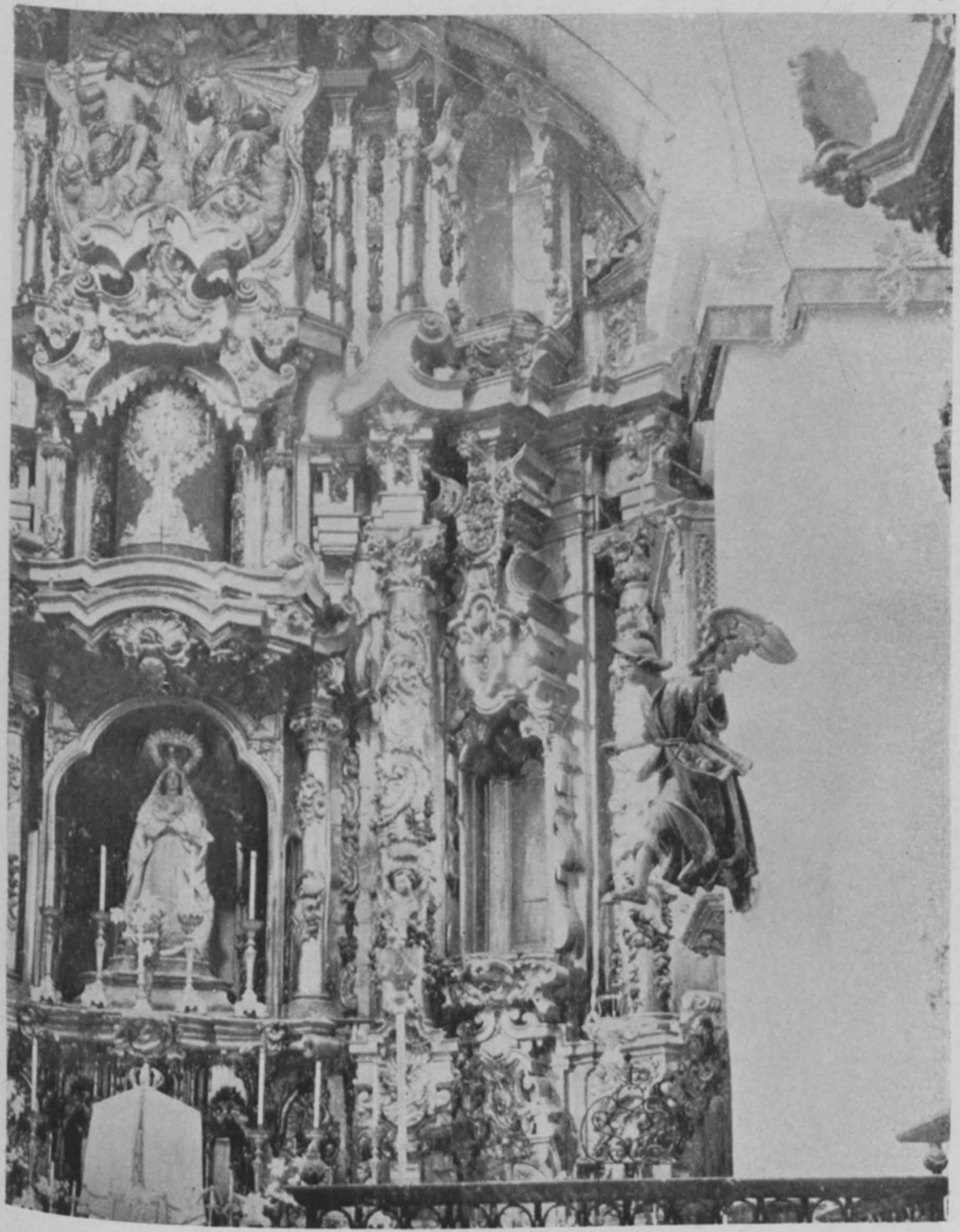

7. Santa María, Cádiz. Retablo mayor, lado derecho. 


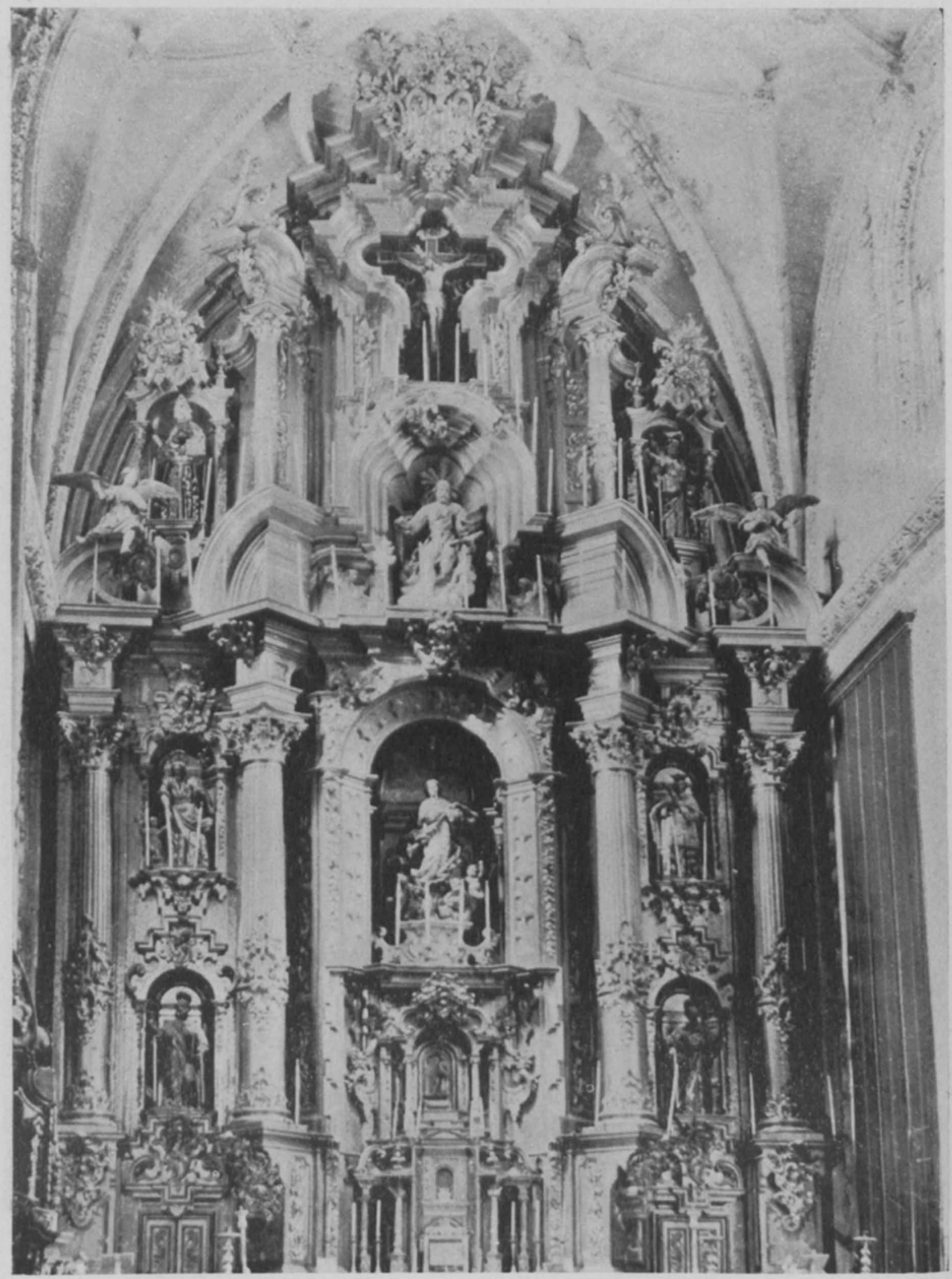

8. San Mateo, Jerez. Retablo mayor. 




9. Santo Domingo, Jerez. Retablo-Tabernáculo en una capilla. 
DOI: http://dx.doi.org/10.22201/iie.18703062e.1957.26.633



10. Colegiata, Jerez. Retablo. 
DOI: http://dx.doi.org/10.22201/iie.18703062e.1957.26.633

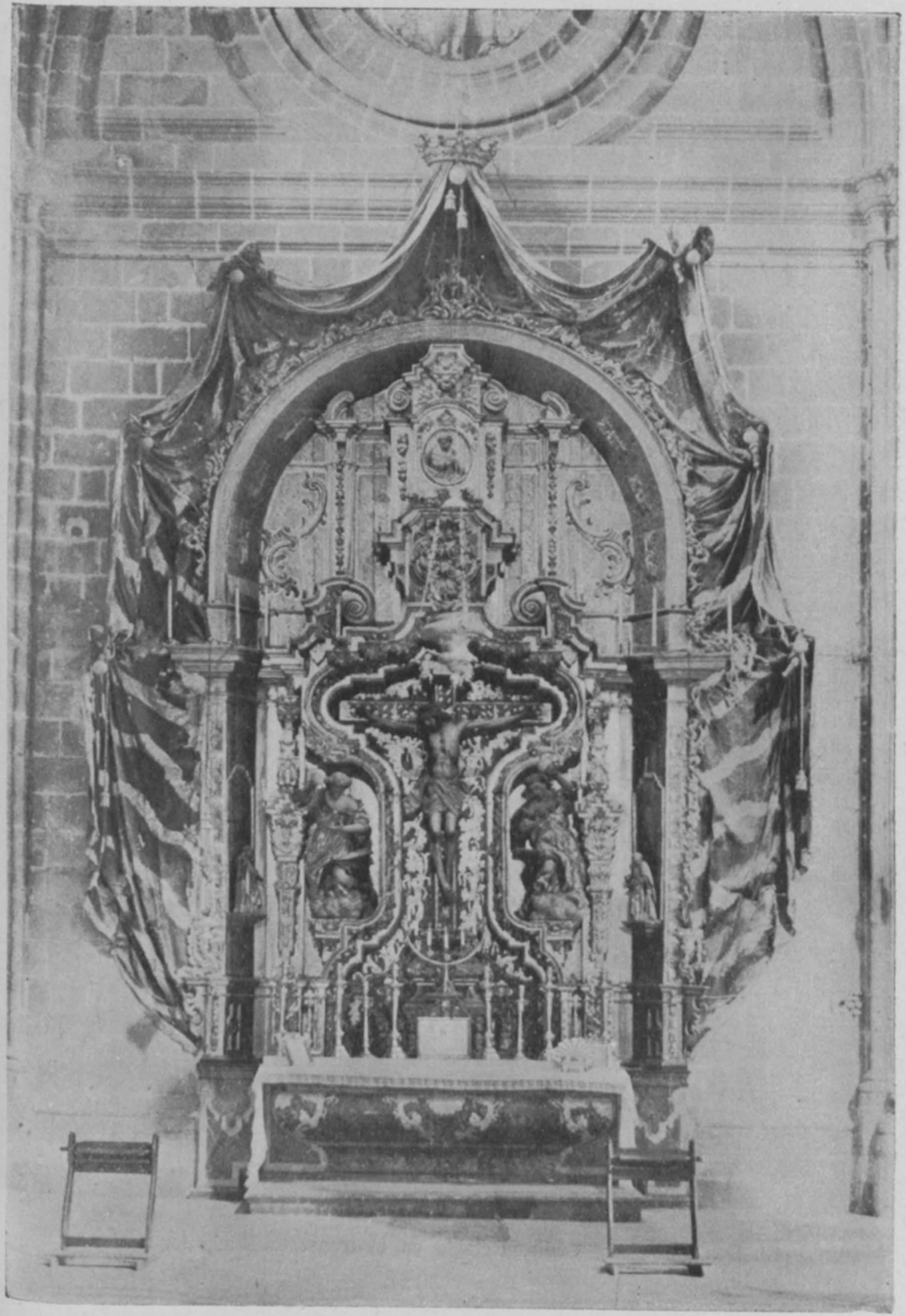

11. Colegiata, Jerez. Retablo al fondo de la nave izquierda. 


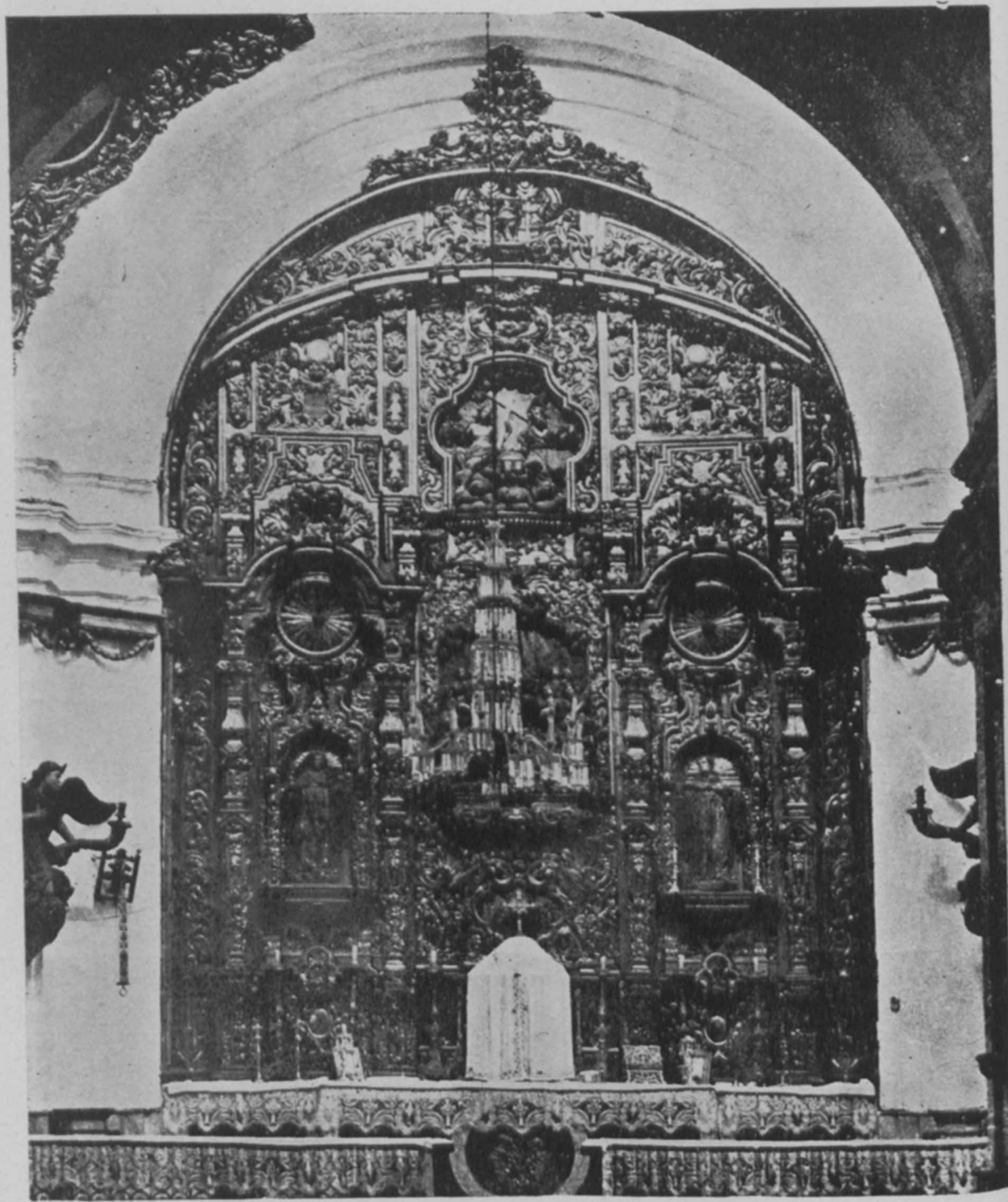

12. San Francisco, Cádiz. Retablo en el transepto. Lado izquierdo. 
here are the ensembles about each side niche and the second level niche. The whole retable is given further variety by the double arch at the apex. Nowhere is the tendency to give architectural importance to the niche more marked than here: the four main vertical accents are reduced to framing elements, and one has the impression of their being suspended before a shifting curtain of highly animated surface.

It is fascinating to see how this concept of the niche-pilaster (that - I have called the "ornamental niche-pilaster") evolves more or less contemporaneously in both Spain and Mexico. In a recent article, ${ }^{22} \mathrm{I}$ have studied this phenomenon in the Italian, Spanish and Mexican areas; it is one of the major design concepts in retable organization for the 18th century. And the retables of Jerez and Cádiz, in addition to their distinctive local character, reveal something of this general trend as well as the infinite variety with which it can be interpreted.

\section{NOTES}

* Photos by the author.

1 Undoubtedly one of the handsomest Rococo interiors of a secular nature occurs in the outwardly unassuming palace of the Marqués de Vila Real de Purullena, in Puerto Santa María, not far from Cádiz. The second floor main salon has boiseries and furniture in the exaggerated Rococo style that is more characteristic of Cuvilliés work in Germany or the Rococo of northern Portuguese interiors, than the style of Louis XV.

2 Cf. R. C. Smith, "Portuguese Baroque Woodcarving", Magazine of Art, October, 1950, pp. 218-222; and "The Portuguese Wood-carved Retable 1600-1750" Belas Artes (Lisbon), 1950, pp. 14-56. In the latter, Smith discusses the quarteläo, which has something of the broken, prismatic quality of the Spanish estipite (cf. pp. 38-39).

3 Stronghold of the so-called Galician Plattenstil; cf. O. Schubert, Geschichte des Barocks, Esslingen, 1908, pp. 224-239, and L. Torres Balbas, "La Arquitectura Barroca en Galicia", Arquitectura, 1920.

4 Cf. R. C. Smith, "João Frederico Ludovice, An 18th century Architect in Portugal", Art Bulletin, xviII, N* 3, pp. 273-370. This article is based on Smith's doctoral thesis, deposited at Harvard University, which explores the classicizing elements of 18th century Portuguese court architecture with great detail. There are excellent biographical notes in both article and thesis on many of the crucial European architects and artists of the late 17 th century and 18th century.

5 Note the retablos mayores of Santa María de la $O$ and of Santo Domingo, for two dramatic variants of the styles practised in Sanlucar after 1760 . 
6. For the 16th and 17 th century in Cádiz, cf. Documentos para la Historia de. Arte en Andalucía, $\mathrm{x}$, (Artifices Gaditanos de Siglo xvi by Enrique Respeto Martín).

7 Romero de Torres, volumes (one of text and one of plates) are the result of work largely done in 1908-1909, but the material was not published in Madrid until 1934. Ifis text is by no means exhaustive, particularly in regard to the 18 th century; there is definite need for a more thorough revision of this part of the Catalogo Monumental de España.

8 Romero de Torres, op. cit., suggests the date of 1636; but $c f$. Femán $y$ Pemartín, El Arte en Cádiz, Madrid, 1930; "El mayor de Santo Domingo, ca. 1694, formado $\mathrm{y}$ fechado atmque la altura a que se encuentran fecha $y$ firma me ha impedido hasta ahora leerlas. Como escultura, el que más interesa es el de los genoveses en el mismo Santo Domingo (in the left transept). Al mismo gusto responden el de los genoveses en la catedral vieja (1671)."

9 As in the retablo mayor of the convento de Santa Clara (1582-1607) and later modified, or the retablo mayor of San Isidoro de Campo (1609-1619); see Gestoso y Pérez, Sevilla Momumental, Sevilla, 1889, III, p. 572; Documentos fara la Historia del Arte en Andahcia, II, p. 50.

10 For a fuller discussion of Italian influence in Spain, through works and the agency of Italian artists employed there, cf. Les Arts Italiens en Espagne, Rome, 1825. There are Italinate aguamaniles in Santa María and in the Cathedral $n$ Cádiz. The palace of the Marqués de Vila Real de Purullena at Puerto Santa María (cf. note 1) was built by a certain Hortuno y Ramírez, born in Naples. For information about works of Spaniards, Portuguese and Hispano-Americans in Italy, cf. Elias Tormo, Momumentos de Españoles, en Roma, y de Portugueses y HispanoAmericanos, Madrid, 1942, 2 vols. The relationship between South Italian and Sicilian polychromatic marble work and that of early 18th century Andalusia is especially interesting.

11 By Frate Giovanni da Monreale, 1692; cf, also, Baird, "The Ornamental Niche-Pilaster", Jourmal of the Society of Architectural Historians, March, 1956.

12 There is an important Italian marble retable in Salamanca, in Las Monjas Agustinas, dating from about the same period; but its composition is less significant, as it serves principally to frame paintings in the style of Ribera. The polychromatic marble retable in the Capilla del Pilar at the Cathedral of Santiago de Compostela (probably by Casas y Novoa) is essentially a tabernacle and dates from the first third of the 18th century. The other marble retable in Cadiz is that in the Capilla de. log Genoveses in the Cathedral, dated by Peman y Pemartin, El Arte de Cádiz, at 1671 .

13 It has a close correlative in the New World in the retablo mayor from the Sanctuary of Nuestra Señora de Copacabana, Copacabana, Bolivia; cf. Kelemen, Baroque and Rococo in Latin America, New York, Mac Millan, 1951, plate 123 (d.).

14 One might note in passing that the use of the solid cylindrical column at this period is not characteristic, but is a continuation of the late Herreresque 
classicism popular in the earlier part of the century in Spain, particularly in the retables of Martínez de Montańes.

15 A morbidly flaccid type of ornament, based on the pendulous lobes of the human ear. It has its greatest currency in the early 17 th century in northern Europe, but can be seen in works from 1650 to 1750 in Spain.

16 Provincia de Cádiz, p. 354.

17 Cf. La Ruta de Colón y las Torres del Condado de Niebla, and Jercz y los Puertos, Madrid, Instituto de Cultura Hispánica, 1946 and 1947, (Cuadernos de Arte, I and II), for excellent illustrations of facades and portals from the southwestern corner of Andalusia.

18 In the retablo mayor of the Colegiata at Osuna or the Sagrario retable from Santiago in Ecija.

19 This type of twisted colum with its deep helices, and almost hollow center, is seen in Mexico on the facade of San Diego at Guanajuato.

20 The marble aguamanil which Romero de Torres calls "sin duda Italiano" is in the sacristy, and appears to be a late 17 th century piece; a similar work is seen in the Cathedral of Cádiz.

21 By Cayetano Acosta, ca. 1770.

22. Baird, "The Ornamental Niche-Pilaster", etc. 